\title{
Fourier Transform Infrared Analysis of Sawdust and Rice Husks Waste: A Raw Material for Eco-Friendly Composite Production
}

\author{
Hamidu, L. A. $\mathrm{J}^{1 *}$, Aroke, U. $\mathrm{O}^{2}$, Osha, O. A ${ }^{2}$, Muhammad, I. M ${ }^{2}$ \\ ${ }^{1}$ Nigerian Building and Road Research Institute, 10 NBRRI Way/I.T. Igbani Street, off Awolowo Way, Jabi, Abuja-Nigeria \\ ${ }^{2}$ Department of Chemical Engineering, Abubakar Tafawa Balewa University, Bauchi, Nigeria
}

\author{
DOI: $10.36348 /$ sjet.2020.v05i10.001 \\ | Received: 13.09.2020 | Accepted: 25.09.2020 | Published: 05.10.2020 \\ *Corresponding author: Lucas Albert Jerome Hamidu
}

\section{Abstract}

Wood has been the most essential components of engineering materials in the building and construction sector. Except for industrial roofing, virtually all roofing in building is done with wood. The flakes or chips generated from resizing of wood logs results in waste known as sawdust waste. The generated sawdust is not used for any economic value; thus, the dumps are either burnt or decomposed in the surrounding and flakes generated from wood plaining are used as adsorbent in poultry house. Nevertheless, bulk of it end up as waste littered on the environment being a menace to the ecosystem. In this work, sawdust from softwood, hardwood and rice husk were processed and characterized to study their functional groups and fingerprints using Fourier transform infrared (FT-IR) spectroscopy, with the aim of identifying its compatibility for use in composite material production with an appropriate binder for comfort of occupants in indoor build environment. The instrument operates on wide range of wave numbers which identify the existing functional group $(4000 \mathrm{~cm}-1-1500 \mathrm{~cm}-1)$ and fingerprint $\left(1500 \mathrm{~cm}^{-1}-400 \mathrm{~cm}^{-1}\right)$ in the assign band at a particular intensity within the wavenumber radiation frequency. The results from this study revealed that, softwood sawdust showed 11 peaks containing mainly aromatic compound dominated by alcohols and phenols, hardwood sawdust showed 21 peaks containing carboxylic acids, aldehydes, alkanes, alkenes and nitrile in addition to the alcohols and phenols in softwood sawdust and rice husks showed 23 peaks in the spectra in addition to the aromatic compounds it contain glutamines, nitriles and carboxylic compounds found in starch and pharmaceutical use. Both materials have the industrial potentials in particleboard production and can provide friendly indoor quality in building environment.

Keywords: Characterization, Composite Materials, FT-IR, Rice husk, Sawdust.

Copyright @ 2020: This is an open-access article distributed under the terms of the Creative Commons Attribution license which permits unrestricted use, distribution, and reproduction in any medium for non-commercial use (NonCommercial, or CC-BY-NC) provided the original author and source are credited.

\section{INTRODUCTION}

Over the years, wood has been the major component in building construction sector as the required engineering material especially when it comes to the roofing, furniture making for both domestic and office accommodation. The world projection on the use of wood pellets and wood chips by the European Commission, as import from the third world countries is estimated to about 80 million tons by 2020 [23]. With this projection, if particulates generated from various sawmills across the country are accounted for, it could place wood commercial outfit in Nigeria in lucrative market of waste wood management and subsequently add value to the economy. Sawmills account for over $93 \%$ of the entire wood processing industries in Nigeria, leading to generation of huge amount of wood waste [23]. Nevertheless, reuse of waste wood for making charcoal briquettes, in steam generating plants, to generate electricity, has shown prospects in developed countries, but very little in developing countries like Nigeria [22]. Furthermore, Nigerian population which is over 203 Million [28] can generate substantial amount of biomass which could be converted to usefulness in particleboard production, and also help to reduce the impact on forests and the environment due to improper disposal.

It has been reported that between 8 and $50 \%$ of the entire wood-based material being utilized yearly for various applications become wastes, typically consisting of solid timber, timber shavings, sawdust, veneer panels and combinations of two or more of them [2]. The development has also led to deforestation, desertification, climate change and global warming [16].

During the resizing or cutting processes, substantial amount of particles are generated and later 
discarded as wastes from the off-cuts as it is commonly used in construction of wooden structures and building, thereby causing menace in the environment [12]. The flakes, chips or species from plaining are mostly used as adsorbent in poultry houses, fuels for local cooking, ashed as fertilizer, adsorption of spent engine oil and are highly combustible such that it becomes difficult to quench in its finest particle sizes.

In modern day's office accommodation, there is quest for befitting furniture which can be produced from lignocellulose agro-biomass waste. Sawdust and rice husks wastes are such typical example of the lignin material which could serve as feedstock for production of particleboard and fiberboard for office partitioning, house hold, desks and so on with a compatible adhesive as binder [2]. Furthermore, the utilization of this waste can lead to industrialization and be source of wealth creation from waste to wealth through recycling process.

Rice husk as the main by-product of the rice milling during dehulling process, is the hard-protective shell of the grain. It is a waste that represents $22 \%$ of rice production and can be potential raw material for particleboard production [9]. Nigerian agriculture, that was once the prime mover of the economy, due to discovery of crude oil in the early $70 \mathrm{~s}$ " in commercial quantity has suffered a great setback in the area of rice farming, resulting into decline into agricultural production, subsequently relying on importation of food stuff such as; rice to meet the demand for the rapid population growth. The annual food import bill is projected to about $\$ 10$ billion ( $\$ 3.7$ trillion) while rice production was about 4.8 million tons in 2016 [21]. Also, the consumption of rice is not comparable to any other food given $10 \%$ annual increments which implies that about 6.72 million tons of rice consumption is projected by 2020 , which is less than 8 million tons expected demand for the country [21].

In recent times, research is intensified on recycling of waste materials for socio-economic reasons. Produced particleboard composite matrix from saw dust and recycled polyethylene terephthalate at different weight ratio by flat-pressed method and suggested the feasibility of using the composite for indoor building based on the favorable physical properties carried out [5] while fabricated particleboard from rice husks mixed with resins and other binders and recommended for usage as paneling and ceiling [4]. Furthermore, transformed rice husk into high-added value product potential into particleboard using different adhesives and recommended the material as potential alternatives for general applications in dry conditions [11]. Sugarcane bagasse and castor oil polyurethane adhesive-based particulate composite and the findings showed that waterproofed particleboard can be used in moist environment [15]. The influence of board density and particle sizes on the homogenous particleboard properties from kelempayan was reported by [20]. However, $80 \%$ of adhesives used as binder in the production of particleboard are derived from urea formaldehyde and is reported carcinogenic. Properties of sawdust can vary depending on the nature or type of wood, some wood are soft and others are hard, in the light of this therefore, samples of sawdust from hardwood and softwood would be assessed to establish the existence of unknown compound using FT-IR spectroscopy for compatibility with non-emitting adhesive.

Fourier transforms infrared (FT-IR) spectra is an instrument used for ideal process of identification and analyzing chemical components in unknown materials, qualitatively or consistency of samples and amount of components in a mixture [3]. Functional groups are identified within the ranges of 4000-1300 $\mathrm{cm}^{-1}$ bands and fingerprints are in the ranges of 1300 $400 \mathrm{~cm}^{-1}$ bands when radiated $[7,8,24]$.

Several authors have used FT-IR techniques to study characteristic properties and functional groups of different compounds, which include; the study on the sorptive removal of ciprofloxacin hydrochloride from simulated waste water using sawdust [6]. Measurement of some particleboard properties bonded with modified carboxymethyl starch of oil palm trunk in determination of new functional groups [26]. Functionalizable polyester with free hydroxyl groups tunable physiochemical and biological properties was reported by [29]. Authors [30] studied the environmental Friendly of urea oxidized starch adhesive with zero formaldehyde emission.

Physical properties of sawdust and rice husk were characterized for suitability as feedstock in particleboard production [16]. The development suggested further study on the functional group of the feedstock for compatibility with appropriate nonemitting adhesive. Research also revealed that little or no attention has been given to the indoor quality of the chemicals used as binders and functional group characterization of the feedstock (sawdust and rice husk) compatibility and determination of possible emission from the usage. This research work is to investigate the functional group of sawdust and rice husk as suitable raw material for production of particleboard and other composite material.

\section{MATERIALS AND METHODS MATERIALS}

The raw materials were sawdust from hardwood and softwood which was collected from Bauchi timber market gathered from sawmill, and rice husk from the rice millers in Bauchi, North Eastern Nigeria. The sawdust and rice husk samples were sieved using different sizes $(1.0-3.5 \mathrm{~mm})$ aperture. The grain sizes that passed through below $3.5 \mathrm{~mm}$ was sun dried for 3 days at environmental conditions [16]. 
Which was followed by packaging of the samples separately and labeled as; softwood sawdust, hardwood sawdust and rice husk.

\section{METHODS}

Fourier transform infrared spectroscopy analysis of the sawdust and rice husks was carried out to study the functional groups using FT-IR-8400S, SHIMADZU model by attenuated total reflection (ATR) according to [18]. $95 \mathrm{mg}$ of the sample was prepared and mixed with $5 \mathrm{mg}$ of ground potassium bromide $(\mathrm{KBr})$, and was pressed into the FT-IR machine, followed by a beam of light reflection on the sample transmission spectra within the wavenumber ranging $4000-400 \mathrm{~cm}^{-1}$ for the system to identify and to pick all functional groups in the specimen within the region [14]. The process was scanned 10 times at $2 \mathrm{~cm}^{-1}$ resolution for data precision and accuracy.

\section{RESULTS AND DISCUSSION \\ Fourier Transform Infrared (FT-IR) Spectra of Sawdust and Rice Husks}

FT-IR spectra of softwood sawdust and rice husks were carried out in this study. The test results for the lignin materials showing the absorbance spectra at different peaks are presented in Figures 1 and 2 and corresponding Tables 1 and 2. The study used standard library for the interpretation of the spectral results presented in the Tables according to [10]. Figure-1 shows detailed absorbance spectra at different waveband for softwood sawdust. The absorbance peaks were located in the wide range of spectral scale between $4000-400 \mathrm{~cm}^{-1}$ wave number [17]. Within the range, 11 peaks appeared in the spectra across the wave number with different functional groups.

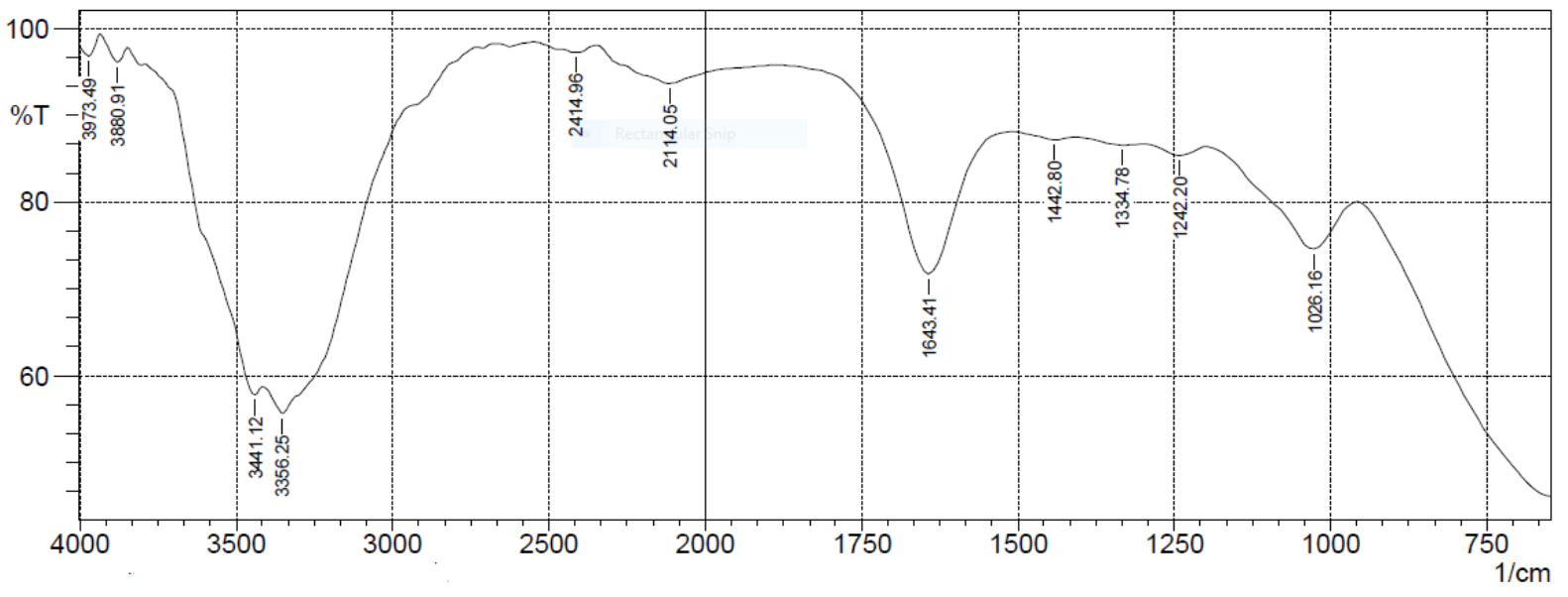

Fig-1: Fourier Transform Infrared (FT-IR) Spectra of Softwood Sawdust

Two peaks appeared in the ranges of $4000-$ $3500 \mathrm{~cm}^{-1}$ with absorbance at (3973.49 and 3880.91) $\mathrm{cm}^{-1}$ corresponding to $\mathrm{O}-\mathrm{H}$ band stretching vibrations with free hydroxyl usually assigning to alcohols and phenols [17]. Two peaks appeared in the ranges of 3500 - 3000 with absorbance at (3441.12 and 3356.25) $\mathrm{cm}^{-1}$ corresponding to $\mathrm{O}-\mathrm{H}$ stretching and $\mathrm{H}$-bonded usually assigned to alcohols and phenols groups [19]. One peak appeared in the ranges of $2500-2000$ with absorbance at $2114.05 \mathrm{~cm}^{-1}$ usually assigned to alkynes functional group [27]. One peak appeared in the ranges of $1750-$ $1500 \mathrm{~cm}^{-1}$ with absorbance at $1643.41 \mathrm{~cm}^{-1}$ which has $\mathrm{N}-\mathrm{H}$ bend, assigned to primary amines functional group [13]. In the ranges of $1500-1250 \mathrm{~cm}^{-1}$, two peaks appeared with absorbance at (1442.8 and 1334.78) $\mathrm{cm}^{-1}$, with C-C stretching (in-ring) at $1442.8 \mathrm{~cm}^{-1}$ is aromatics and $\mathrm{C}-\mathrm{N}$ stretching at $1334.78 \mathrm{~cm}^{-1}$ is aromatics amines
[10]. In the ranges of $1250-1000 \mathrm{~cm}^{-1}$ two peaks appeared with absorbance at (1242.2 and 1026.16) $\mathrm{cm}^{-1}$ which has $\mathrm{C}-\mathrm{N}$ stretching is usually assigned to aliphatic amines groups [1].

The result of softwood FT-IR shows mainly alcohols and phenols due to the presence of water molecule in the sawdust. The alkynes functional group shows the presence of unsaturated hydrocarbon, which can covalently have joined with the amines group. The aromatic compound is the major functional group showing presence of alcohols and phenols compounds [32]. Detailed results interpretation is presented on Table1. It can be deduced from the results that the softwood sawdust does not contain emitting compounds which could be detrimental to living organism. 
Hamidu, L. A. J et al., Saudi J Eng Technol, October, 2020; 5(10): 343-350

Table-1: Vibrational Frequencies and Assignments for Softwood Sawdust

\begin{tabular}{|l|l|l|l|}
\hline Frequencies $\left(\mathbf{c m}^{-1}\right)$ & Intensity $\mathbf{( \% )}$ & Assignments & Functional group/fingerprint \\
\hline 3973.49 & 96.835 & O $-\mathrm{H}$ stretch & alcohols, phenols \\
\hline 3880.91 & 96.099 & $\mathrm{O}-\mathrm{H}$ stretch & alcohols, phenols \\
\hline 3441.12 & 57.807 & $\mathrm{O}-\mathrm{H}$ stretch, H - bonded & alcohols, phenols \\
\hline 3356.25 & 55.711 & $\mathrm{~N}-\mathrm{H}$ stretch & primary, secondary amines, amides \\
\hline 2114.05 & 93.679 & $-\mathrm{C} \equiv \mathrm{C}-$ stretch & alkynes \\
\hline 1643.41 & 71.728 & $-\mathrm{C}=\mathrm{C}-$ stretch & alkenes \\
\hline 1442.80 & 87.184 & $\mathrm{C}-\mathrm{C}$ stretch, (in-ring) & aromatics \\
\hline 1334.78 & 86.563 & $\mathrm{C}-\mathrm{N}$ stretch & aromatics amines \\
\hline 1242.20 & 85.387 & $\mathrm{C}-\mathrm{N}$ stretch & aliphatic amines \\
\hline 1026.16 & 74.61 & $\mathrm{C}-\mathrm{N}$ stretch & aliphatic amines \\
\hline
\end{tabular}

Figure-2 shows detailed FT-IR results of the hardwood sawdust spectral investigation. After 10 scanning in the range of $4000-400 \mathrm{~cm}^{-1}$ frequency band, 21 peaks results were generated as presented in Fig-2 [14].

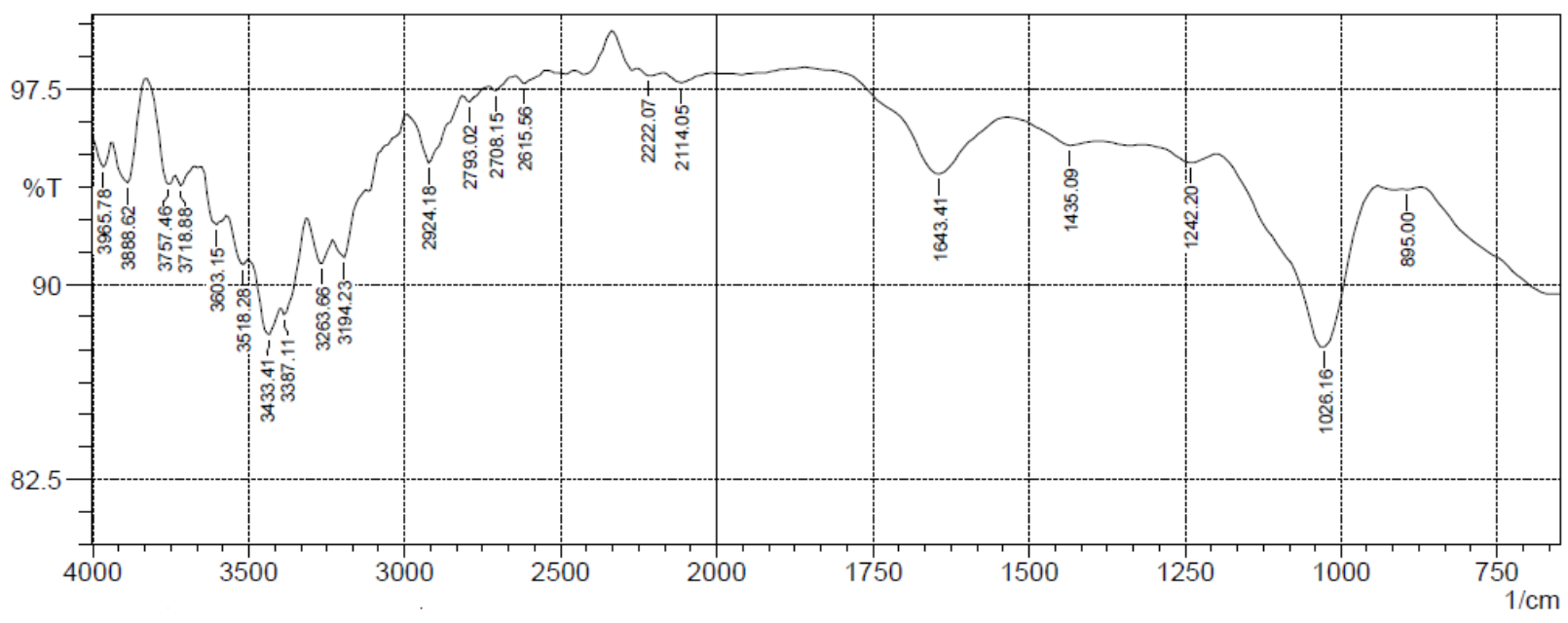

Fig-2: Fourier Transform Infrared (FT-IR) Spectra of Hardwood Sawdust

In the ranges of $4000-3500 \mathrm{~cm}^{-1}$ frequency six peaks appears with the absorbance at (3965.76, 3880.62 , 3757.46, 3718.88, 3603.15 and 3518.26) with $\mathrm{O}-\mathrm{H}$ stretching free hydroxyls usually assigned to alcohols and phenols groups [17]. In the ranges $3500-$ $3000 \mathrm{~cm}^{-1}$ frequency four peaks appeared with absorbance at (3433.41, 3387.11, 3263.66 and 3194.23) $\mathrm{cm}^{-1}$ with $\mathrm{O}-\mathrm{H}$ stretching and $\mathrm{H}$-bonded peak appeared at $3433.41 \mathrm{~cm}^{-1}$ shows presence of alcohols and phenols groups [14]. N-H stretching peak appeared at 3387.11 $\mathrm{cm}^{-1}$ presents primary amines, secondary amines and amides groups [25] and absorbance at (3263.66 and $3194.23) \mathrm{cm}^{-1}$ with $\mathrm{O}-\mathrm{H}$ stretching is assigned to carboxylic acid groups [27]. In the ranges of 3000 $2500 \mathrm{~cm}^{-1}$ frequency; four peaks appeared with absorbance at $(2924.18,2793.02,2708.15$ and 2615.56) $\mathrm{cm}^{-1}$ with C-H stretching peak appeared at $2924.18 \mathrm{~cm}^{-1}$ is usually assigned to alkanes saturated hydrocarbon, while absorbance at $(2793.03$ and 2708.15$) \mathrm{cm}^{-1}$ with $\mathrm{H}-\mathrm{C}=\mathrm{O}$ : $\mathrm{C}-\mathrm{H}$ stretching is usually assigned to aldehydes, possible combination with urea could result into formation of urea formaldehyde which is an emitting compound [17]. O-H stretching peak for absorbance at $2615.56 \mathrm{~cm}^{-1}$ is carboxylic acid group which is used as supplement [27]. In the ranges $2500-$ $2000 \mathrm{~cm}^{-1}$, two peaks appeared with absorbance at (2222.07 and 2114.05) $\mathrm{cm}^{-1},-\mathrm{C} \equiv \mathrm{N}$ stretching peak absorbance at $2222.07 \mathrm{~cm}^{-1}$ is usually assigned to nitriles group and $-\mathrm{C} \equiv \mathrm{C}$ stretching peak with absorbance at $2114.05 \mathrm{~cm}^{-1}$ is assigned to alkynes group [13]. In the ranges $1750-1500 \mathrm{~cm}^{-1}$ a peak appeared at absorbance of $1643.41 \mathrm{~cm}^{-1}$ having $-\mathrm{C}=\mathrm{C}-$ stretching is assigned to alkenes group unsaturated hydrocarbon [3]. From the ranges of $1500-750$ region is the fingerprints. In the ranges $1500-1250 \mathrm{~cm}^{-1}$ with $\mathrm{C}-\mathrm{C}$ stretching (in-ring) appeared at absorbance of 1435.09 $\mathrm{cm}^{-1}$ is aromatic group. In the ranges $1250-1000 \mathrm{~cm}^{-1}$, two peaks appeared with absorbance at (1242.20 and 1026.16) $\mathrm{cm}^{-1}$ and $\mathrm{C}-\mathrm{N}$ stretching is aliphatic amines group. $=\mathrm{C}-\mathrm{H}$ bend stretching in ranges $1000-750 \mathrm{~cm}^{-1}$ peak appeared at absorbance of $895 \mathrm{~cm}^{-1}$ is assigned to alkenes group [30]. Detailed analysis is presented on Table-2 for hardwood sawdust vibrational frequencies and the corresponding assigned wave bonds. 
Hamidu, L. A. J et al., Saudi J Eng Technol, October, 2020; 5(10): 343-350

\begin{tabular}{|c|c|c|c|}
\hline Frequency band $\left(\mathrm{cm}^{-1}\right)$ & $\% \mathrm{~T}$ & Bond & Functional group \\
\hline 3965.78 & 94.513 & $\mathrm{O}-\mathrm{H}$ stretch & alcohols, phenols \\
\hline 3888.62 & 93.896 & $\mathrm{O}-\mathrm{H}$ stretch & alcohols, phenols \\
\hline 3757.46 & 93.852 & $\mathrm{O}-\mathrm{H}$ stretch & alcohols, phenols \\
\hline 3718.88 & 93.786 & $\mathrm{O}-\mathrm{H}$ stretch & alcohols, phenols \\
\hline 3603.15 & 92.300 & $\mathrm{O}-\mathrm{H}$ stretch & alcohols, phenols \\
\hline 3518.28 & 90.754 & $\mathrm{O}-\mathrm{H}$ stretch & alcohols, phenols \\
\hline 3433.41 & 88.066 & $\mathrm{O}-\mathrm{H}$,stretch, $\mathrm{H}-$ bonded & alcohols, phenols \\
\hline 3387.11 & 88.833 & $\mathrm{~N}-\mathrm{H}$ stretch & primary, secondary amines, amides \\
\hline 3263.66 & 90.807 & $\mathrm{~N}-\mathrm{H}$ stretch & primary, secondary amines, amides \\
\hline 3194.23 & 91.23 & $\mathrm{O}-\mathrm{H}$ stretch & carboxylic acids \\
\hline 2924.18 & 94.652 & $\mathrm{C}-\mathrm{H}$ stretch & alkanes \\
\hline 2793.03 & 97.009 & $\mathrm{H}-\mathrm{C}=\mathrm{O}: \mathrm{C}-\mathrm{H}$ stretch & aldehydes \\
\hline 2708.15 & 97.443 & $\mathrm{H}-\mathrm{C}=\mathrm{O}: \mathrm{C}-\mathrm{H}$ stretch & aldehydes \\
\hline 2615.56 & 97.711 & $\mathrm{O}-\mathrm{H}$ stretch & carboxylic acids \\
\hline 2222.07 & 98.013 & $\mathrm{C} \equiv \mathrm{N}$ stretch & nitriles \\
\hline 2114.05 & 97.750 & $-\mathrm{C} \equiv \mathrm{C}-$ stretch & alkynes \\
\hline 1643.41 & 94.244 & $-\mathrm{C}=\mathrm{C}-$ stretch & alkenes \\
\hline 1435.09 & 95.333 & $\mathrm{C}-\mathrm{C}$ stretch(in-ring) & aromatics \\
\hline 1242.20 & 94.663 & $\mathrm{C}-\mathrm{N}$ stretch & aliphatic amines \\
\hline 1026.16 & 87.600 & $\mathrm{C}-\mathrm{N}$ stretch & aliphatic amines \\
\hline 895 & 93.647 & $=\mathrm{C}-\mathrm{H}$ bend & alkenes \\
\hline
\end{tabular}

From Table-2, the hardwood sawdust shows 21 peaks in the region indicating the existence of varieties of phytochemicals in the wood residue; this could be due to the nature of the wood species such mahogany. In this sample, varieties of functional groups were found containing saturated and unsaturated hydrocarbons, carboxylic acids and aldehyde groups, usually present as starting material for pharmaceuticals industry being derivatives of hydrocarbon [33].
Figure-3 shows the detailed absorbance spectra of rice husks at different waveband, located in the wide range of spectral scale between $4000-400 \mathrm{~cm}^{-1}$ wavenumber [14]. There are 23 peaks appeared in the spectra across the entire wavenumber with different intensities, existing bonds, corresponding functional groups and fingerprint regions.

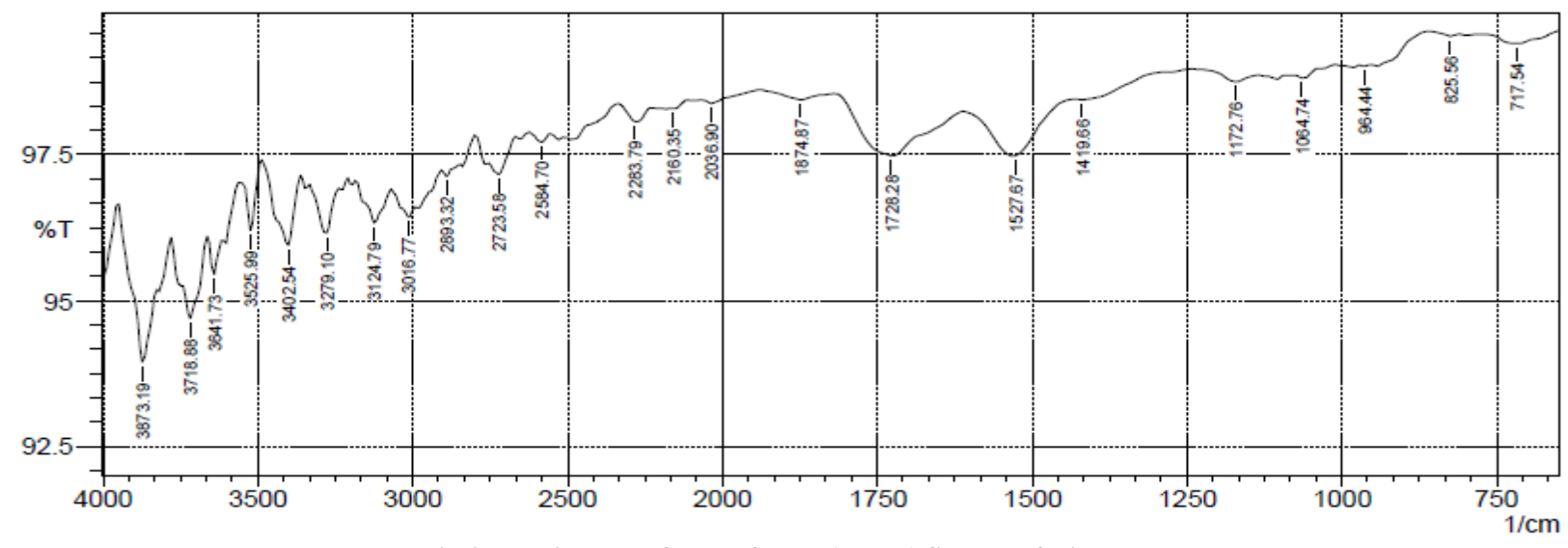

Fig-3: Fourier Transform Infrared (FT-IR) Spectra of Rice Husks

The result shows that four peaks appeared in the ranges of $4000-3500 \mathrm{~cm}^{-1}$ with absorbance at (3873.19, 3718.88, 3641.73 and 3525.99) which corresponds to $\mathrm{O}-\mathrm{H}$ stretching vibrations with free hydroxyl group at $3641.73 \mathrm{~cm}^{-1}$ and $\mathrm{O}-\mathrm{H}$ stretching with $\mathrm{H}$ - bonded at $3525.99 \mathrm{~cm}^{-1}$ usually assigned to alcohols and phenols [17]. While absorbance at 3873.19 and $3718.88 \mathrm{~cm}^{-1}$ peaks were not defined and assign. In the ranges of $3500-3000 \mathrm{~cm}^{-1}$, four peaks appeared with corresponding absorbance at 3402.54 with $\mathrm{N}-\mathrm{H}$ stretching assigned to primary, secondary amines and amides, 3279.10 with $-\mathrm{C}$ (triple bond) $\mathrm{C}-\mathrm{H}$ : $\mathrm{C}-\mathrm{H}$ stretching assigned to alkynes, 3124.79 with $\mathrm{O}-\mathrm{H}$ stretching assigned to carboxylic acids and 3016.77 with $\mathrm{C}-\mathrm{H}$ stretching assigned to aromatic compound [27]. In the region of $3000-2500 \mathrm{~cm}^{-1}$, three peaks were located with absorbance at $2893.32 \mathrm{~cm}^{-1}$ with $\mathrm{C}-\mathrm{H}$ stretching assigned to alkenes saturated hydrocarbon, 
$2729.10 \mathrm{~cm}^{-1}$ with $\mathrm{H}-\mathrm{C}=\mathrm{O}: \mathrm{C}-\mathrm{H}$ stretching usually assigned to aldehydes functional groups and 2584.70 $\mathrm{cm}^{-1}$ with $\mathrm{C}$ (triple bond) $\mathrm{N}$ stretching assigned to nitriles functional groups. In the region of $2500-2000 \mathrm{~cm}^{-1}$, three peaks appeared at absorbance of $2283.79 \mathrm{~cm}^{-1}$ with no functional group assigned to the band, 2160.90 $\mathrm{cm}^{-1}$ with $-\mathrm{C} \equiv \mathrm{C}-$ stretching usually assigned to alkynes unsaturated hydrocarbon and $2036.90 \mathrm{~cm}^{-1}$ with no band assigned as functional group [14]. In the region of $2000-1750 \mathrm{~cm}^{-1}$, a peak appeared at $1874.87 \mathrm{~cm}^{-1}$ also not assigned to any functional group. While in the region of $17500-1500 \mathrm{~cm}^{-1}$ two peaks appeared at absorbance of $1728.28 \mathrm{~cm}^{-1}$ with $\mathrm{C}=\mathrm{O}$ stretching usually assigned to aldehydes, esters, saturated aliphatic hydrocarbon and $1527.67 \mathrm{~cm}^{-1}$ with $\mathrm{N}-\mathrm{O}$ asymmetric stretching usually assigned to nitro compounds [13]. The fingerprint region is in the ranges of $1500-400$ $\mathrm{cm}^{-1}$ [14]. In the region of $1500-1250 \mathrm{~cm}^{-1}$ waveband, a peak was located at $1419.66 \mathrm{~cm}^{-1}$ with $\mathrm{C}-\mathrm{C}$ stretching (in-ring) assigned to aromatics fingerprint without bending [25]. Two peaks appeared in the fingerprint region of $1250-1000 \mathrm{~cm}^{-1}$ at absorbance of 1172.76 $\mathrm{cm}^{-1}$ with $\mathrm{C}-\mathrm{H}$ wag stretching vibrations is usually assigned to alkyl halides due to the presence of halogenated compound in the material and $1064.74 \mathrm{~cm}^{-1}$ with $\mathrm{C}-\mathrm{N}$ stretching is assigned to aliphatic amines due to the presence of amines [27]. While in the fingerprint region of $1000-750 \mathrm{~cm}^{-1}$ two peaks were located at absorbance of $946.44 \mathrm{~cm}^{-1}$ with $=\mathrm{C}-\mathrm{H}$ bending usually assigned to alkenes unsaturated hydrocarbons which could be due to fermentation of the rice husks during processing and at $825.56 \mathrm{~cm}^{-1}$ absorbance with $=\mathrm{C}-\mathrm{H}$ bending reveals the presence of halogens assigned to alkyl halides [31]. And in the region of $750-400 \mathrm{~cm}^{-1}$ was a peak at $717.54 \mathrm{~cm}^{-1}$ with $\mathrm{C}-\mathrm{H}$ "oop" assigned to aromatics.

Table-3: Vibrational Frequencies and Assignments for Rice Husks

\begin{tabular}{|c|c|c|c|}
\hline Frequencies $\left(\mathrm{cm}^{-1}\right)$ & Intensity (\%) & Assignments & Functional group/fingerprint \\
\hline 3873.19 & 93.9396 & No bond assigned & \\
\hline 3718.88 & 94.6913 & No bond assigned & \\
\hline 3641.73 & 95.4462 & $\mathrm{O}-\mathrm{H}$ stretch (s), free hydroxyl & Alcohols, phenols \\
\hline 3525.99 & 95.4462 & $\mathrm{O}-\mathrm{H}$ stretch $(\mathrm{s}), \mathrm{H}-$ bonded & Alcohols, phenols \\
\hline 3402.54 & 95.9437 & $\mathrm{~N}-\mathrm{H}$ stretch & primary, secondary amines, amides \\
\hline 3279.10 & 96.1602 & $-\mathrm{C}(\equiv) \mathrm{C}-\mathrm{H}: \mathrm{C}-\mathrm{H}$ stretch & alkynes (terminal) \\
\hline 3124.79 & 96.3327 & O-H stretch & carboxylic acids \\
\hline 3016.77 & 96.4325 & $\mathrm{C}-\mathrm{H}$ stretch & aromatics \\
\hline 2893.32 & 97.1259 & $\mathrm{C}-\mathrm{H}$ stretch & Alkanes \\
\hline 2723.58 & 97.1610 & $\mathrm{H}-\mathrm{C}=\mathrm{O}: \mathrm{C}-\mathrm{H}$ stretch & aldehydes \\
\hline 2584.70 & 97.7194 & $\mathrm{C}(\equiv) \mathrm{N}$ stretch & nitriles \\
\hline 2283.79 & 98.0705 & No bond assigned & \\
\hline 2160.90 & 98.2925 & $-\mathrm{C}(\equiv) \mathrm{C}-$ stretch & alkynes \\
\hline 2036.90 & 98.3777 & No bond assigned & \\
\hline 1847.87 & 98.4437 & No bond assigned & \\
\hline 1728.28 & 97.4845 & $\mathrm{C}=\mathrm{O}$ stretch & aldehydes, saturated aliphatic \\
\hline 1527.67 & 97.4784 & $\mathrm{~N}-\mathrm{O}$ asymmetric stretch & Nitro compounds \\
\hline 1419.66 & 98.4465 & C-C stretch (in-ring) & Aromatics \\
\hline 1172.78 & 98.7517 & $\mathrm{C}-\mathrm{H}$ wag $(-\mathrm{CH} 2 \mathrm{X})$ & alkyl halides \\
\hline 1064.74 & 98.8168 & $\mathrm{C}-\mathrm{N}$ stretch & aliphatic amines \\
\hline 964.44 & 99.0164 & $=\mathrm{C}-\mathrm{H}$ bend & alkenes \\
\hline 825.56 & 99.5338 & $=\mathrm{C}-\mathrm{H}$ bend & alkyl halides \\
\hline 717.54 & 99.4096 & C-H "oop" & aromatics \\
\hline
\end{tabular}

Table-3, shows that rice husks contain alkyl halides a derivative of halogen family [31]; the nitro and nitriles are due to the presence of nitrogenous compounds found in food stuffs along with the carboxylic compounds which could also be as presence of glutamines in starchy materials such as rice. This will serve as promising raw material due to the presence of glutamine proteins in rice husk to readily bond with adhesive [2].

From FT-IR spectra in Tables 1, 2 and 3, the softwood sawdust, hardwood sawdust and rice husks are having the following functional group in common: alcohols and phenols which can undergo a wide range of reaction leading to complete ionization; primary amines, secondary amines and amides indicating the nitrogen containing compounds with great role in biochemistry and pharmaceuticals produced from plants; alkenes and alkynes the unsaturated hydrocarbon ready to polymerize to saturation; aromatics and aliphatic amines when combine with halogen will form alkyl halides. However; some differences observed in the FT-IR spectra are the functional groups found in hardwood sawdust and rice husks but not in softwood sawdust are the carboxylic acid which can provides protein and lipids chemistry; alkanes the saturated hydrocarbon, aldehyde and nitriles the nitrogenous compounds that can covalently interact with adhesive. 
While the following were found exclusively in rice husks; saturated aliphatic and alkyl halides which can offer range of reactions for organic synthesis [34].

Based on the analysis, rice husks contain all the functional groups in softwood and hardwood sawdust. The softwood sawdust which is preferred mostly in construction due to its termites and water resistant is in abundance, compared to hardwood which is rarely used in the construction. Thus; consideration for the use of softwood sawdust as raw material for particleboard is recommended in this work. Rice husk is also available due to the increase in rice production backed by the Federal Government policy on agriculture to boast food production. Both materials have potentials for sustainable industrial application in particleboard production in eco-friendly environment.

\section{CONCLUSION}

In this study sawdust from softwood and hardwood, and rice husks were processed and characterized. The FT-IR showed 11 peaks for softwood sawdust implying low phytochemicals, 22 peaks in hardwood sawdust implying high existence of phytochemicals and 23 peaks in rice husks. The study shows that softwood sawdust materials will provide covalent interaction with non-emitting binder due to absence of aldehyde as shown in the FT-IR study. The hardwood sawdust shows the presence of aldehydes which could lead to increase in content of urea formaldehyde containing adhesive, nitriles, carboxylic and saturated and unsaturated hydrocarbon functional group. While rice husk in addition to aromatic group, contains alkyl halides and glutamines proteins in starch can provide covalent interaction with adhesive in production of eco-friendly composite materials for sustainable environment. The results of all the FT-IR study has shown the compatibility of the characterized sawdust and rice husk from agro bio based as promising feedstock in particleboard production.

\section{ACKNOWLEDGEMENT}

The authors gratefully thank the Nigerian Building and Road Research Institute, Jos, North central, Nigeria for using their Laboratory and equipment, and timber dealers in Bauchi for allowing the collection of sawdust and rice husks wastes.

\section{CONFLICT OF INTEREST}

The authors declared that there is no conflict of interest.

\section{REFERENCES}

1. Adjova, E., Olodo, E., \& Doko, V. (2018). Study of the implementation of waste wood, plastics and polystyrene from industries for various applications in the building industry. Retrieved from http://challengest.scienceafrique.fr/results_phase1. php

2. Akinyemi, B. A., Olamide, O., \& Oluwasogo, D. (2019). Formaldehyde free particleboards from wood chip wastes using Glutaraldehyde modified cassava starch as binder. Case Studies in Construction Materials, 11, e00236. Doi: 10.1016/j.cscm.2019.e00236

3. Al-Kadhemy, M. F. H., Rasheed, Z. S., \& Salim, S. R. (2016). Fourier Transform Infrared Spectroscopy for Irradiations Coumarin Doped Polystyrene Polymer Films by Alpha Ray, Journal of Radiation Research and Applied Science, 9(3), 321-331. Doi:101016/j.jrras.2016.02.004

4. Asha, A. (2017). Fabrication of Particleboards from Rice Husk, International Journal of Modern Engineering Research, 7(5), 30-38.

5. Atoyebi, O. D., Adediran, A. A., \& Adisa, C. O. (2018). Physical and Mechanical Properties Evaluation of Particle Board Produced from Saw Dust and Plastic Waste, International Journal of Engineering Research in Africa, 40:1-8. doi:10.4028/www.scientific.net/JERA.40.1

6. Bajpai, S. K., Bajpai, M., \& Rai, N. (2012). Sorptive Removal of Ciprofloxacin Hydrochloride from Simulated Wastewater using Sawdust: Kinetic Study and Effect of pH. 38(5):674-682 http://dx.doi.org/10.4314/wsa.v38i54

7. Barrueso-Martínez, M. L., Del Pilar FerrándizGómez, T., Romero-Sánchez, M. D., \& MartínMartínez, J. M. (2003). Characterization of evabased adhesives containing different amounts of rosin ester or polyterpene tackifier. The Journal of Adhesion, 79(8-9), 805-824. Doi: 10.1080/00218460309547.

8. Chau, V. V., Bunge, F., Duffy, J., \& Hood, L. (2011). Advances in Thermal Insulation of Extruded Polystyrene Foams, Journal of Cellular Polymers, 30(3), 137-155.

9. Ciannamea, E. M., Marin, D. C., Ruseckaite, R. A., \& Stefani, P. M. (2017). Particleboard Based on Rice Husk: Effect of Binder Content on Processing Conditions, Journal of Raw Materials. Doi: 10.7569/JRM.2017.634125.

10. Cortes, S. (2010). Theory and Interpretation of Infrared spectroscopy spectra. Retrieved from https://personal.utdallas.edu/ scortes/ochem/OChe m_Lab1/recit_notes/ir_presentation.pdf

11. Da Silva César, A. A., Bufalino, L., Mendes, L. M., De Almeida Mesquita, R. G., De Paula Protásio, T., Mendes, R. F., \& Ferreira Andrade, L. M. (2017). Transforming Rice Husk into a High-Added Value Product: Potential for Particleboard Production, Ciência Florestal, Santa Maria. 27(1), 303-313.

12. Derikvand, M., \& Pangh, H. (2016). A Modified Method for Shear Strength Measurement of Adhesive Bonds in Solid Wood, Peer-Review Article; Adhesive Bond Strength, BioResources. 11(1), $354-364$. 
13. Elbadawi, M., Osman, Z., Paridah, T., Nasroun, T., \& Kantiner, W. (2015). Mechanical and Physical Properties of Particleboards made from Ailanthus Wood and UF resin Fortified by Acacias Tannins Blend. Journal of Materials and Environmental Sciences. 6(4), 1016 - 1021.

14. Ernest, Z. (2015, January 23). How can I distinguish functional group region and fingerprint region in a infrared spectrum? Retrieved from https://socratic.org/questions/howcan-i-distinguish-functional-group-region-andfingerprint-region-in-a-infrar

15. Fiorelli, J., Sartori, D. D., Cravo, J. C. M., Junior, H. S., Rossignolo, J. A., Nascimento, M. F., \& Lahr., F. A. R. (2016). Sugarcane Bagasse and Castor Oil Polyurethane Adhesive-based Particulate Composite, Journal of Materials Research, 16(2),439-446. Doi: 10.1590/S151614392013005000004

16. Hamidu, L. A. J., Aroke, U. O., Osha, O. A., \& Muhammad, I. M. (2019). Characterization of Sawdust and Rice Husks Properties for Particleboard Production, International Journal of Latest Technology in Engineering, Management \& Applied Science (IJLTEMAS), 8(6), 100 - 104. ISSN 2278-2540.

17. Hamidu, L. A. J., Aroke, U. O., Osha, O. A., \& Muhammad, I. M. (2019). Fourier Transform Infrared Spectroscopy and Scanning Electron Microscopy Characterization of Adhesive Produced From Polystyrene Waste, Path of Science. 5(12), 3001-3008. doi:10.22178/pos.534.

18. Kariuki, S. W., Wachira, J., Kawira, M., \& Leonard, G. M. (2019). Characterization of Prototype Formulated Particleboards from Agro industrial Lignocellulose Biomass Bonded with Chemically Modified Cassava Peel Starch, Advances in Materials Science and Engineering Volume 2019, Article ID 1615629, 15 pages https://doi.org/10.1155/2019/1615629.

19. Labcompare. (n. d.). Infrared Spectroscopy (IR/FTIR). Retrieved October 10, 2019, from https://www.labcompare.com/Spectroscopy/165Infrared-Spectroscopy-IR-

FTIR/?search=Infrared+Spectroscopy

20. Lias, H., Kasim, J., Johari, N. A. N., \& Mokhtar, I. L. M. (2014). Influence Of Board Density And Particle Sizes On The Homogenous Particleboard Properties From Kelempayan (Neolamarckia Cadamba), International Journal of Latest Research in Science and Technology. 3(6):173176 http://www.mnkjournals.com/ijlrst.htm.

21. Osabuohien, E., Okorie, U., \& Osabohien, R. (2018). Rice Production and Processing in Ogun
State, Nigeria: Qualitative Insights from Farmers' Association. In Obayelu, E. (Eds).Food Systems Sustainability and Environmental Policies in Modern Economics (pp. 188-215), Hershey, PA: IGI Global. DOI: 10.4018/978-1-5225-36314.ch009.

22. Owoyemi, J. M., Zakariya, H. O., \& Elegbede, I. O. (2016). Sustainable Wood Waste Management in Nigeria, Environment Socio-Economic Study. 4(3):1-9. Doi: 10.1515/environ-2016-0012.

23. Peter, A., Albert, O., \& Anthony, U. (2017). Nigerian Wood Waste: A Potential Resource for Economic Development, Journal of Allied Science Environmental Management. 21(2), 246 - 251. http://dx.doi.org/10.4314/jasem.v21i2.4.

24. Rouabah, F., Dadache, D., \& Haddaoui, N. (2012). Thermophysical and Mechanical Properties of Polystyrene: Influence of Free Quenching. ISRN Polymer Science, 2012, 1-8. doi: $10.5402 / 2012 / 161364$

25. Sanches, N. B., Pedro, R., Diniz, M. F., Mattos, E., Cassu, S. N., \& Dutra, R. C. L. (2013). Infrared Spectroscopy Applied to Materials Used as Thermal Insulation and Coatings. 5(4), 421-430.

26. Selamat, M. E., Sulaiman, O., Hashim, R., Hiziroglu, S., Nadhari, W. N. A. W., Sulaiman, N. S., \& Razali, M. Z. (2014). Measurement of some particleboard properties bonded with modified carboxymethyl starch of oil palm trunk. Measurement, 53, 251-259. Doi: 10.1016/j.measurement.2014.04.001

27. WebSpectra. (2019). Table of IR Absorptions. Retrieved October 10, 2019, from https://webspectra.chem.ucla.edu/irtable.html

28. Worldometer (2020). www.worldometer

29. You, Z., Cao, H., Gao, j., Shin, P. H., Day, B. W., \& Wang, Y. (2010). A Functionalizable Polyester with Free Hydroxyl Groups and Tunable Physiochemical and Biological Properties, a Journal of Biomaterials. 31(2010), 3129-3138. Doi:10.1016/J.Biomaterials.2010.01.023

30. Zhao, X., Peng, L., Wang, H., Wang, Y., \& Zhang, H. (2018). Environment-friendly urea-oxidized starch adhesive with zero formaldehyde-emission. Carbohydrate Polymers, 181, 1112-1118. Doi: 10.1016/j.carbpol.2017.11.035

31. www.Alkyl halides. Retrieved $16^{\text {th }}$ March 2020.

32. www.Chem.libretexts.org Retrieved on $15^{\text {th }}$ March, 2020.

33. www.Carboxylic.org Retrieved on $17^{\text {th }}$ March, 2020.

34. www.Organic Chemistry.libretexts.org Retrieved on $19^{\text {th }}$ August, 2020. 